\title{
The Role of Job Embeddedness on Quality of Work Life and Organizational Citizenship Behavior: A Study on Menoufia University Hospitals
}

\author{
Wageeh Nafei ${ }^{1}$ \\ ${ }^{1}$ University of Sadat City, Egypt \\ Correspondence: Wageeh Nafei, University of Sadat City, Menoufia, Egypt. E-mail: dr.wageeh1965@yahoo.com
}

Received: August 4, 2014

Accepted: September 23, 2014

Online Published: March 27, 2015

doi:10.5539/ijbm.v10n4p215

URL: http://dx.doi.org/10.5539/ijbm.v10n4p215

\begin{abstract}
Background: Currently, healthy organizations such as hospitals have found out the importance of Quality of Work Life (QWL) of their personnel. QWL is directed to enhancement of job satisfaction and improvement of services quality to patient hospital and high performance.

Purpose: Job Embeddedness (JE) is one of constructs that contribute to the formation and increasing of QWL. Thus this study investigates the effect of JE on QWL and Organizational Citizenship Behavior (OCB) at Menoufia University Hospitals.

Research Design/Methodology: To assess positive JE (JE Questionnaire, Mitchell et al., 2001), QWL (QWL Survey Seashore et al., 1983; Cammann et al., 1983; National Institute for Occupational Safety and Health, 2002), OCB (OCB Questionnaire Podsakoff, 1990; Konovsky \& Pugh, 1994; and Konovsky \& Organ, 1996) are used. Out of the 338 questionnaires that were distributed, 315 usable questionnaires were returned, a response rate of $93 \%$.
\end{abstract}

Findings: It has been paid to how JE factors such as fit, links and sacrifice have an impact on QWL and OCB. In other words, fit, links and sacrifice significantly correlated with QWL and OCB. The study findings support the view that JE, QWL, and OCB are related constructs.

Practical implications: The study suggests that the Menoufia University Hospitals in Egypt can improve QWL by influencing its JE, specifically, by developing fit, links and sacrifice. The study provided that it is necessary to pay more attention to the dimensions of JE as a key source for organizations to enhance the competitive advantage which is of prime significance for QWL and OCB.

Originality/value: JE is valuable for evaluating employee retention at Menoufia University Hospitals in Egypt. The study observes that there is a critical shortage of JE and that a greater understanding of the factors that influence the QWL and OCB, including fit, links and sacrifice, is of great importance. Therefore, this study examines the relationship between JE, QWL and OCB among employees at Menoufia University Hospitals in Egypt.

Keywords: job embeddedness, quality of work life, organizational citizenship behavior

\section{Introduction}

Job Embeddedness (JE) theory represents one of these new perspectives (Holtom et al., 2006), focusing on factors that encourage an employee to remain with an organization. Several studies reveal that JE predicts incremental variation in turnover after controlling for traditional turnover predictors, such as job satisfaction and quit intentions (Crossley et al., 2007; Mallol et al., 2007).

JE theory is a broad constellation of psychological, social, and financial influences on employee retention (Yao et al., 2004).

These influences are present on the job, as well as outside the employee's immediate work environment, and are often likened to strands in a "web" or "net" in which a person can become "stuck" (Mitchell et al., 2001).

$\mathrm{JE}$ is comprised of (1) the links one has to others, (2) the fit with the organization and community, and (3) how much one would have to sacrifice to change jobs (Lee et al., 2004; Holtom \& Inderrieden, 2006). JE research has 
extended to other outcomes such as performance and social capital (Sekiguchi et al., 2008).

$\mathrm{JE}$ is a retention or anti-withdrawal construct. JE is composed of factors such as the overall fit employees have with the organization. It would yield positive outcomes. JE should lead to the development of human and social capital for two reasons. First, for highly embedded individuals, there is good fit of the employees' existing knowledge, skills and abilities with the requirements of the organization that provides opportunities for the natural extension and development of additional and complimentary skills. Second, the highly embedded employees have many links with more important individuals which provide opportunities to develop additional social capital. In fact, there is a positive relationship between JE and social capital but found declines in social capital development over time (Ng \& Feldman, 2010).

JE represents rich social ties, job fit, and personal investment in a job or organization and the community that in turn create opportunities for the employee to extend and develop new skills and social ties with others (Holtom et al., 2006).

JE has numerous features; these are (a) work or organizational options by way of choosing your clients, (b) empowerment, or mentoring activities, and (c) non-worker social embeddedness (Emmerik \& Sanders, 2004) which includes direct links to family, non-work activities, off-the-job interests, and job and embeddedness in the organization (Mitchell et al., 2001).

\section{Literature Review}

\subsection{Job Embeddedness}

The concept "Embeddedness" has been used in the sociology discipline to explain the process by which social relations influence and constrain economic actions (Sekiguchi et al., 2008).

Embeddedness represents the collection of forces that keep an employee in a job (Halbesleben \& Wheeler 2008).

Embeddedness further suggests that a number of strands connect an employee to his or her family in a social, psychological and financial web. This web includes work and non-work friends, groups, the community and the physical environment in which the employee lives. The greater the number of links between the person and the web, the more firmly an employee is bound to the job and the organization (Mallol et al., 2007).

Job Embeddedness (JE) is relatively a new concept and is under-researched in the hospitality management and marketing literature (Karatepe \& Ngeche, 2011).

JE consists of three independent elements: the fit (match) between a person's job and their community and their personal life space; the links a person has to other people or activities; and the extent to which a person would have to make a sacrifice to break these links-hence it represents what an employee will sacrifice on leaving the organization. In combination, these three elements exert pressure on employees to stay at their current organization (Ng \& Feldman, 2010).

$\mathrm{JE}$ is the strength of individuals' links to other people, team and groups. It may associate with one's intentions to stay or leave an organization. Specifically, JE was accepted as representing the sum of effects that keep employees in their current employment (Mitchell, 2001).

$\mathrm{JE}$ is an employee retention theory which evolved from the unfolding model of voluntary employee turnover (Lee et al., 1996). There are three dimensions of JE. The three dimensions are important both on and off the job. These dimensions can be defined as follows (Mitchell et al., 2001).

Links: Links mean that each individual is linked to other people, teams, and organizations officially or unofficially. A lot of organizations put a lot of importance on these links (Mitchell, 2001). Individuals having formal or informal connections with colleagues in the workplace and with friends and other people in the community are highly embedded in their jobs. Holtom et al. (2006) argue that family and other social institutions in the community have direct influences on individuals and their decision making. Under these circumstances, more links in the organization and the community refer to elevated levels of JE. For example, older and married employees with children are less likely to leave the organization, because there are a number of connections that exist between them and other people in the organization and in the community (Mitchell et al., 2001).

Fit: Fit is how compatible the employees feel with the company, organization or the local community he/she belongs to. Mitchell et al. (2001) suggested that the more the individual feels fitted to the job, colleagues and the business culture, the lower turnover is. If there is fit between employees, personal values and future plans and the demands of his job as well as the organizational culture, then these employees are highly embedded in their jobs. In addition, such a fit should exist between employees and the community. For example, the weather, amenities and general culture of the location have direct effects on individuals and their decision making (Holtom et al., 2006). 
Employees who do no perceive such a fit are not embedded in their jobs.

Sacrifice: Sacrifice means the opportunity cost of turnover, which is the perceived cost of physical or psychological convenience sacrificed when leaving a current job. Recent research suggests that job attitude has relatively little influence on the stay or turnover of the employees. Factors other than job satisfaction, organizational commitment, and job alternative are stand out to understand turnover (Park \& Lee, 2004). Individuals are aware of what they are going to lose as a result of their voluntary turnover (Holtom et al., 2006; Mitchell et al., 2001). For example, they give up colleagues and lose the current and future career and promotional opportunities in the organization. In addition, individuals leaving an attractive and safe community may not have the same environment in another location. Therefore, individuals are aware of such costs and become highly embedded in their jobs.

\subsection{Quality of Work Life}

Quality of Work Life (QWL) is a concept of behavioral science, and the term was first introduced by Davis in 1972 (Mathur, 1989; Hian \& Einstein, 1990).

QWL can be defined as a process by which an organization responds to employee needs by developing mechanisms to allow them to share fully in making the decisions that design their lives at work. QWL is a philosophy, a set of principles, which holds that people are the most important resource in the organization as they are trustworthy, responsible and capable of making valuable contribution and they should be treated with dignity and respect (Robbins, 1989).

The key elements of QWL in the literature include job security, job satisfaction, better reward system, employee benefits, employee involvement and organizational performance (Havlovic, 1991). Studies demonstrate that employees with high QWL tend to report high levels of identification with their organizations, job satisfaction, job performance and lower levels of turnover and personal alienation (Efraty et al., 1991).

QWL is defined as employee satisfaction with a variety of needs through resources, activities, and outcomes stemming from participation in the workplace (Sirgy et al. 2001).

QWL has been well recognized as a multi-dimensional construct and it may not be universal or eternal. The key concepts captured and discussed in the existing literature include job security, better reward systems, higher pay, opportunity for growth, participative groups, and increased organizational productivity. In the scientific management tradition, satisfaction with QWL was thought to be based solely on "extrinsic" traits of the job: salaries and other tangible benefits, and the safety and hygiene of the workplace. By contrast, the human relations approach stresses that, while extrinsic rewards are important, "intrinsic rewards" are key predictors of productivity, efficiency, absenteeism and turnover. These intrinsic rewards include traits specific to the work done, the "task content" : skill levels, autonomy and challenge (Beauregard, 2007).

One conceptualization of QWL, based on need-hierarchy theory of Maslow, regards QWL as employee satisfaction of seven sets of human developmental needs: (1) health and safety needs, (2) economic and family needs, (3) social needs, (4) esteem needs, (5) actualization needs, (6) knowledge needs, and (7) esthetic needs (Marta et al., 2011).

In sum, QWL is defined as the favorable condition and environment of employees benefit, employees' welfare and management attitudes towards operational workers as well as employees in general.

There are eight aspects in which employees perceptions towards their work organizations could determine their QWL: adequate and fair compensation; safe and health environment; development of human capacities; growth and security; social integrative constitutionalism; the total life space and social relevance (Walton, 1974).

There is a plethora of literature highlighting the factors critical for the assessment of QWL (Srinivas, 1994). Comprehensive delineation of the QWL concept is found in three major works. Other researchers have attempted to measure QWL in a variety of settings using combinations of various questionnaires such as job satisfaction, organizational commitment, alienation, job stress, organizational identification, job involvement and finally work role ambiguity, conflict, and overload were studied as proxy measures of QWL (Levine et al., 1984). The key concepts captured in QWL include job security, better reward systems, higher pay, opportunity for growth, and participative groups among others (Havlovic, 1991; Straw \& Heckscher, 1984). QWL can be measured by the feelings that employees have towards their jobs, colleagues, and companies would enhance a chain effect leading to organization's growth and profitability (Heskett et al., 1997).

According to Robins (1995) QWL is a process by which an organization responds to employees' needs by developing mechanisms to allow them to share fully in making the decisions that design their lives at work. The 
key elements of QWL in the literature include job security, job satisfaction, better reward system, employee benefits, employee involvement and organizational performance (Havlovic, 1991; Scobel, 1975).

For the purpose of this study, QWL is defined as the favorable condition and environment of employees benefit, employees' welfare and management attitudes towards operational workers as well as employees in general.

\subsection{Organizational Citizenship Behavior}

Bateman and Organ (1983) were the first to use the term "OCB" in 1983 (Podsakoff et al., 2000). OCB is one of the most widely studied topics in organizational behavior research (Podsakoff \& MacKenzie, 1997; Ehrhart \& Naumann, 2004). OCB is one of the emerging management concepts that are being emphasized for the organizational effectiveness, efficiency and profitability of the organizations (Ertürk et al., 2004).

$\mathrm{OCB}$ is an extra role and behaviours such as teamwork with employees, approaching workplace earlier and leaving late, helping other employees, using organizational possessions with care, and disseminating positively in organization (Turnispeed \& Rassuli, 2005).

OCB can improve co-worker and managerial productivity, provide superior efficiency in resource use and allocation, reduce managerial expenses, provide better coordination of organizational activities across individuals, groups and functional departments, improve organizational attractiveness for high quality new recruits, increase stability in the organization's performance, and enhance organizational capability to adapt effectively to environmental changes (Cohen \& Vigoda, 2000; Ertürk et al., 2004).

OCB is individual behavior that is discretionary, not directly or explicitly recognized by the formal reward system, and that in the aggregate promotes the effective functioning of the organization. OCB can be defined as behaviors that are not formally rewarded (Organ, 1988).

High levels of OCB should lead to a more efficient organization and help bring new resources into the organization. In Organ's explanation, securing needed resources refers not only to the attraction of new members or raw materials, but also to such intangible factors as company good will, or the external image and reputation of the organization. Thus, customer perceptions of the organization's products or services could be an external assessment of effectiveness that is influenced by OCB (Organ, 1988).

OCB can assist organizations to develop performance and increase competitive periphery as it encourages employees to perform beyond the formal job requirement. It can assist the organization to be successful in current environment and accelerate novelty and creative approaches for organizations (Nemeth \& Staw, 1989).

OCB can be classified into two groups. They are OCB-Organizational and OCB Individual. OCB-Organizational benefits the organization, in general, such as adhering to informal rules devised to maintain order. OCB-Individual benefits specific individuals and indirectly contributes the organization, such as taking a personnel interest in other employees (Williams \& Anderson, 1991).

OCB is individual behaviours that promote the goods of the organization by contributing to its social and psychological environment. Such behaviours include helping another employee finish a project, providing helpful advice or suggestions, and offering positive feedback on work tasks (Podsakoff et al., 1993).

OCB has been related to wide range of antecedents such as job satisfaction, leadership, fairness, perceived organizational support, psychological contract, and commitment (Ravichandran et al., 2007).

OCB is referred to as "contextual performance" or "prosocial organizational behaviour" to emphasize the voluntary nature of the activity and to distinguish it from "task performance" or one's assigned duties (Borman \& Motowidlo, 1997). There are some features of OCB. They are (1) beneficial and informal behavior or gestures, (2) discretionary; not enforceable requirement of the role or job description, (3) not directly or explicitly recognized by formal reward system; uncompensated individual contributions in the workplace that does role requirement, and (4) enhances the effective functioning of the organizations in the aggregate (Paine \& Organ, 2000).

Organ (1988) identified five categories of OCB (1) Altruism: the helping of an individual coworker on a task, (2) Courtesy: alerting others in the organization about changes that may affect their work, (3) Conscientiousness: carrying out one's duties beyond the minimum requirements, (4) Sportsmanship: refraining from complaining about trivial matters, and (5) Civic Virtue: participating in the governance of the organization.

There are five dimensions of OCB. They are as follows (Organ, 1988; Podsakoff et al., 1990):

Altruism can be called simply helping or helpfulness. Altruism consists of voluntarily actions that help others with an organizationally relevant task such as voluntarily helping orientation of a new employee, sharing sales strategies, teaching employees useful knowledge or skills, showing employees how to accomplish difficult tasks 
(Borman et al., 2001). Altruism (e.g., helping new colleagues and freely giving time to others) is naturally concentrating toward other individuals but adding to group efficiency by increasing the performance of individuals.

Conscientiousness is a discretionary behavior that goes well beyond the minimum role requirement level of the organization, such as obeying rules and regulations, not taking extra breaks, working extra-long days (MacKenzie et al., 1993). More conscientiousness for an employee means more responsibility and less supervision (Podsakoff \& MacKenzie, 1997). Altruism and conscientiousness are the two major or overarching dimensions of OCB (Borman et al., 2001). Conscientiousness (e.g., efficient use of time and going beyond minimum expectations) increases the efficiency of individual and the group.

Sportsmanship is the demonstration of willingness to tolerate minor and temporary personnel inconveniences and impositions of work without grievances, complaints, appeals, accusations, or protest, thus conserving organizational energies for task accomplishment and lightening the loads of managers (Organ \& Ryan, 1995). Sportsmanship (e.g., avoiding complaining and whining) improves the quantity of time spent on productive activities in the organization.

Courtesy, or gestures, is demonstrated in the interest of preventing creations of problems for co-workers. A courteous employee avoiding creating problems for co-workers reduces intergroup conflict so managers do not fall into a pattern of crisis management (Podsakoff \& MacKenzie, 1997). Courtesy (e.g., advance notices, reminders, and communicating appropriate information) facilitates avoidance of problems and boosts productive use of time.

Civic Virtue is a behavior on the part of an individual that indicates that an employee responsibly participates in, is involved in, or concerned about the life of the company (Podsakoff et al., 1990). This dimension represents a macro level interest in, or commitment to the organization. This behavior shows willingness to participate actively in managerial events, to monitor organization's environment for threats and opportunities, to look out for organization's best interest. These behaviors reflect an employee's recognition of being a part of the organization (Podsakoff et al., 2000). Civic Virtue (e.g., serving to communities and voluntarily attending functions) endorses the interests of the organization.

Each dimension of OCB offers a different rationale for this relationship. Altruism or helping coworkers makes the work system more productive because one worker can utilize his or her free time to assist another on a more urgent task. Acts of civic virtue may include offering suggestions for cost improvement or other resource saving ideas, which may directly influence efficiency. To a lesser extent, conscientious employees, as well as those who avoid personal gain or other negative behaviors, demonstrate compliance with company policies and maintain predictable, consistent work schedules, increasing the reliability of the service. As reliability increases, the costs of rework are reduced, making the unit more efficient (Berry \& Parasuraman, 1991).

\section{Research Model}

The proposed comprehensive conceptual model is presented in Figure 1. The diagram below shows that there is one independent variable of JE. There are two dependent variables of QWL and OCB. It shows the rational links among the variables. The research model is as shown in Figure 1 below.

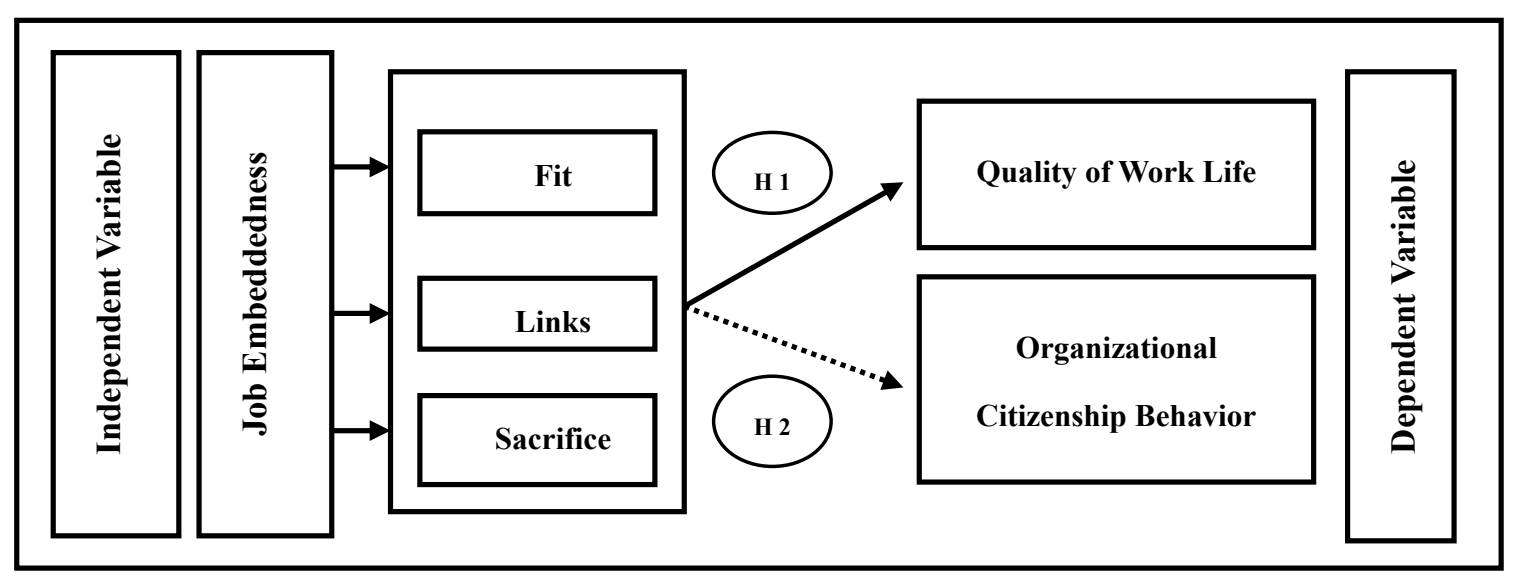

Figure 1. Proposed comprehensive conceptual model 
The research framework suggests that JE has an impact on QWL and OCB. JE as measured consists of fit, links, and sacrifice (Mitchell et al., 2001).

QWL is measured in terms of the moral conditions of the work environment, job characteristics, wages and rewards, team work, head's method in supervision, and participation in decision-making (Seashore et al., 1983; Cammann et al., 1983; National Institute for Occupational safety and Health, 2002).

OCB is measured in terms of altruism, courtesy, sportsmanship, conscientiousness, and civic virtue (Podsakoff, 1990; Konovsky \& Pugh, 1994; Konovsky \& Organ, 1996).

\section{Research Questions and Hypotheses}

The researcher found the research problem through two sources. The first source is to be found in previous studies, and it turns out that there is a lack in the number of literature reviews that dealt with the analysis of the relationship between JE, QWL and OCB for employees at Menoufia University Hospitals in Egypt. This called for the researcher to test this relationship in the Egyptian environment. The second source is the pilot study, which was conducted in an interview with (30) employees at Menoufia University Hospitals in Egypt in order to identify the relationship between JE, QWL and OCB at Menoufia University Hospitals in Egypt. The researcher found through the pilot study several indicators; notably the important and vital role that could be played by JE in developing and improving QWL and OCB Menoufia University Hospitals in Egypt.

The research process includes both questions and hypotheses. The research questions of this study are as follows:

Q1: What is the nature and the extent of the relationship between JE (Fit, Links, Sacrifice) and QWL at Menoufia University Hospitals.

Q2: What is the statistically significant relationship between JE (Fit, Links, Sacrifice) and OCB at Menoufia University Hospitals.

The following hypotheses were developed to the test if there is a significant correlation between JE, QWL and OCB.

H1: JE (Fit, Links, Sacrifice) of employees has no statistically significant effect on QWL at Menoufia University Hospitals.

H2: JE (Fit, Links, Sacrifice) of employees has no statistically significant relationship with OCB at Menoufia University Hospitals.

\section{Research Methods}

\subsection{Population and Sample}

The study subjects are employees at Menoufia University Hospitals in Egypt, including physicians, nurses and administrative staff. The total population is 2839 employees. Determination of sample size was calculated using the formula (Daniel, 1999) as follows:

$$
\mathrm{n}=\frac{N \times(Z)^{2} \times P(1-P)}{d^{2}(N-1)+(Z)^{2} \times P(1-P)}
$$

The number of samples obtained by 382 employees at Menoufia University Hospitals is presented in Table 1.

Table 1. Distribution of the sample size

\begin{tabular}{llll}
\hline Job Category & Number & Percentage & Size of Sample \\
\hline Physicians & 486 & $17.1 \%$ & $338 \times 17.1 \%=134$ \\
Nurses & 1675 & $59.0 \%$ & $338 \times 59.0 \%=189$ \\
Administrative Staff & 678 & $23.9 \%$ & $338 \times 23.9 \%=34$ \\
\hline Total & $\mathbf{2 8 3 9}$ & $\mathbf{1 0 0 \%}$ & $\mathbf{3 3 8}$ X 100\%= 338 \\
\hline
\end{tabular}

Source: Personnel Department at Menoufia University, 2014.

\subsection{Method of Data Collection}

The goal of this study was to examine the relationships between JE, QWL and OCB at Menoufia University Hospitals. A survey research method was used to collect data in this study.

The questionnaire included four questions, relating to JE, QWL, OCB and biographical information of employees 
at Menoufia University Hospitals. A total of 338 questionnaires were sent out in March, 2014 and collected in May 2014.

Three hundred and twenty five effective questionnaires were collected ( $96 \%$ collection rate). Ten ineffective ones (with unanswered questions, duplicated entries and inappropriate marks) were excluded, and the number of effective ones was 315 (93\% valid collection rate). The sample distribution is listed in Table 2.

Table 2. Characteristics of items of the sample

\begin{tabular}{|c|c|c|c|}
\hline Variables & & Number & Percentage \\
\hline \multirow{4}{*}{ 1- Job Title } & Physicians & 130 & $41.3 \%$ \\
\hline & Nurses & 150 & $47.6 \%$ \\
\hline & Administrative Staff & 35 & $11.1 \%$ \\
\hline & Total & 315 & $100 \%$ \\
\hline \multirow{3}{*}{ 2- Sex } & Male & 120 & $38.1 \%$ \\
\hline & Female & 195 & $61.9 \%$ \\
\hline & Total & 315 & $100 \%$ \\
\hline \multirow{3}{*}{ 3- Marital Status } & Single & 100 & $31.7 \%$ \\
\hline & Married & 215 & $68.3 \%$ \\
\hline & Total & 315 & $100 \%$ \\
\hline \multirow{4}{*}{ 4- Age } & Under 30 & 125 & $39.7 \%$ \\
\hline & From 30 to 45 & 120 & $38.1 \%$ \\
\hline & Above 45 & 70 & $22.2 \%$ \\
\hline & Total & 315 & $100 \%$ \\
\hline \multirow{4}{*}{ 5- Educational Level } & Secondary School & 100 & $31.7 \%$ \\
\hline & University & 150 & $47.6 \%$ \\
\hline & Post Graduate & 65 & $20.6 \%$ \\
\hline & Total & 315 & $100 \%$ \\
\hline \multirow{4}{*}{ 6- Period of Experience } & Less than 5 years & 100 & $31.7 \%$ \\
\hline & From 5 to 10 & 80 & $25.4 \%$ \\
\hline & More than 10 & 135 & $42.9 \%$ \\
\hline & Total & 315 & $100 \%$ \\
\hline
\end{tabular}

\subsection{Research Variables and Methods of Measuring}

The 18-item scale JE section is based on Mitchell et al., (2001). There were six items measuring fit, six items measuring links, and six items measuring sacrifice.

The 36-item scale QWL section is based on Seashore et al., (1983); Cammann et al., 1983; National Institute for Occupational Safety and Health, 2002. There were six items measuring the moral conditions of the work environment, six items measuring job characteristics, six items measuring wages and rewards, six items measuring team work, six items measuring the head's method in supervision, and six items measuring the participation in decision-making.

The 15-item scale OCB section is based on Podsakoff, (1990), Konovsky \& Pugh (1994), and Konovsky \& Organ (1996). There were three items measuring altruism, three items measuring courtesy, three items measuring sportsmanship, three items measuring conscientiousness, and three items measuring civic virtue.

Responses to all items scales were anchored on a five (5) point Likert scale for each statement which ranges from (5) "full agreement," (4) for "agree," (3) for "neutral," (2) for "disagree," and (1) for "full disagreement."

\subsection{Methods of Data Analysis and Testing Hypotheses}

The researcher has employed the following methods: (1) The Alpha Correlation Coefficient (ACC), (2) Multiple Regression Analysis (MRA), and (3) the statistical testing of hypotheses which includes F- test and T-test. They are found in SPSS.

\section{Hypotheses Testing}

Before testing the hypotheses and research questions, descriptive statistics were performed to find out means and standard deviations of JE, QWL and OCB. 
Table 3 lists the mean and standard deviation among variables. The mean of each variable is more than three, and this result indicates that the study subjects in general have a higher level of JE, OC and JP. The different facets of JE (fit, links, and sacrifice) are examined. Most respondents identified the presence of sacrifice $(\mathrm{M}=3.36$, $\mathrm{SD}=0.939)$. This was followed by fit $(\mathrm{M}=3.21, \mathrm{SD}=1.12)$, and links $(\mathrm{M}=3.14, \mathrm{SD}=0.955)$.

Table 3. Shows the mean and standard deviations of JE, QWL and OCB

\begin{tabular}{llll}
\hline Variables & The Dimension & Mean & $\begin{array}{c}\text { Standard } \\
\text { Deviation }\end{array}$ \\
\hline \multirow{4}{*}{ JE } & Fit & 3.2185 & 1.12401 \\
& Links & 3.1476 & 0.95520 \\
& Sacrifice & 3.3651 & 0.93908 \\
\cline { 2 - 4 } Qotal Measurement & $\mathbf{3 . 2 4 3 7}$ & $\mathbf{0 . 9 7 5 3 2}$ \\
\hline \multirow{4}{*}{ ThL } & The Moral Conditions of the Work Environment & 3.6921 & 1.32950 \\
& Job Characteristics & 3.6709 & 1.27388 \\
& Wages and Rewards & 3.7672 & 1.23142 \\
& Tam Work & 3.7926 & 1.24708 \\
& Head's Method in Supervision & 3.7471 & 1.25889 \\
& Participation in Decision-Making & 3.7804 & 1.18854 \\
\cline { 2 - 4 } OCB & Total Measurement & $\mathbf{3 . 7 4 1 7}$ & $\mathbf{1 . 2 2 9 7 8}$ \\
& Altruism & 3.6561 & 1.22079 \\
& Courtesy & 3.7069 & 1.22654 \\
& Sportsmanship & 3.6370 & 1.31429 \\
& Conscientiousness & 3.6222 & 1.22205 \\
& Civic virtue & 3.6201 & 1.38103 \\
\cline { 2 - 4 } & Total Measurement & $\mathbf{3 . 6 4 8 5}$ & $\mathbf{1 . 2 1 2 7 7}$ \\
\hline
\end{tabular}

The different facets of QWL are examined. Most respondents identified the presence of the moral conditions of the work environment $(\mathrm{M}=3.69, \mathrm{SD}=1.32)$. This was followed by job characteristics $(\mathrm{M}=3.67, \mathrm{SD}=1.27)$, wages and rewards $(\mathrm{M}=3.76, \mathrm{SD}=1.23)$, team work $(\mathrm{M}=3.79, \mathrm{SD}=1.24)$, head's method in supervision $(\mathrm{M}=3.74, \mathrm{SD}=1.25)$, and participation in decision-making $(\mathrm{M}=3.78, \mathrm{SD}=1.18)$.

The different facets of $\mathrm{OCB}$ are examined. Most respondents identified the presence of altruism $(\mathrm{M}=3.65$, $\mathrm{SD}=1.22)$. This was followed by courtesy $(\mathrm{M}=3.70, \mathrm{SD}=1.22)$, sportsmanship $(\mathrm{M}=3.63, \mathrm{SD}=1.31)$, conscientiousness $(\mathrm{M}=3.62, \mathrm{SD}=1.22)$, and civic virtue $(\mathrm{M}=3.62, \mathrm{SD}=1.38)$.

\subsection{Evaluating Reliability}

Table 4 shows the results of the reliability test for each variable of JE, QWL and OCB. ACC was decided to exclude variables that had a correlation coefficient of less than 0.30 when the acceptable limits of ACC range from 0.60 to 0.80 , in accordance with levels of reliability analysis in social sciences (Nunnally \& Bernstein, 1994).

Table 4. Reliability of JE, QWL and OCB

\begin{tabular}{|c|c|c|c|}
\hline Variables & The Dimension & $\begin{array}{ll}\text { Number } \\
\text { Statement }\end{array}$ & ACC \\
\hline \multirow{4}{*}{$\mathbf{J E}$} & Fit & 6 & 0.8744 \\
\hline & Links & 6 & 0.7607 \\
\hline & Sacrifice & 6 & 0.7728 \\
\hline & Total Measurement & 18 & 0.9363 \\
\hline \multirow{7}{*}{ QWL } & The Moral Conditions of the Work Environment & 6 & 0.9682 \\
\hline & Job Characteristics & 6 & 0.9640 \\
\hline & Wages and Rewards & 6 & 0.9703 \\
\hline & Tam Work & 6 & 0.9714 \\
\hline & Head's Method in Supervision & 6 & 0.9454 \\
\hline & Participation in Decision-Making & 6 & 0.9382 \\
\hline & Total Measurement & 36 & 0.9929 \\
\hline \multirow{6}{*}{ OCB } & Altruism & 3 & 0.9722 \\
\hline & Courtesy & 3 & 0.9218 \\
\hline & Sportsmanship & 3 & 0.9535 \\
\hline & Conscientiousness & 3 & 0.9137 \\
\hline & Civic virtue & 3 & 0.9590 \\
\hline & Total Measurement & 15 & 0.9839 \\
\hline
\end{tabular}


To assess the reliability of the data, Cronbach's alpha test was conducted. Table 4 shows the reliability results for JE, OC and JP. All items had alphas above 0.60 and were therefore excellent, according to Langdridge's (2004) criteria.

The 18 items of JE are reliable due to the fact that the ACC is 0.9363 . The fit, which consists of six items, is reliable since the ACC is 0.8744 while the six items related to links is reliable as the ACC is 0.7607 . Furthermore, the sacrifice, which consists of six items, is reliable due to the fact that the ACC is 0.7728 .

The 36 items of QWL are reliable because the ACC is 0.9929 . The six items of the moral conditions of the work environment scales are reliable due to the fact that the ACC is 0.9682 . The job characteristics, which consists of six items, is reliable since the ACC is 0.9640 . The six items related to wages and rewards are reliable as ACC is 0.9703 . Furthermore, the six items of team work scales are reliable due to the fact that the ACC is 0.9714 . The head's method in supervision, which consists of six items, is reliable since the ACC is 0.9454 . The six items related to participation in decision-making are reliable as ACC is 0.9382 .

The 15 items of OCB are reliable due to the fact that the ACC is 0.9839 . The altruism, which consists of three items, is reliable since the ACC is 0.9722 while the three items related to courtesy is reliable as the ACC is 0.9218 .

Also, the sportsmanship, which consists of three items, is reliable due to the fact that the ACC is 0.9535 . The conscientiousness, which consists of three items, is reliable since the ACC is 0.9137 while the three items related to civic virtue is reliable as the ACC is 0.9590 .

\subsection{The Correlation among the Research Variables}

Table 5. Means, standard deviations and intercorrelations among variables

\begin{tabular}{llllll}
\hline Variables & Mean & $\begin{array}{l}\text { Std. } \\
\text { Deviation }\end{array}$ & JE & QWL & OCB \\
\hline Job Embeddedness & 3.24 & 0.975 & 1.000 & & \\
Quality of Work Life & 3.74 & 1.229 & $0.364^{* * *}$ & 1.000 & 1.000 \\
Organizational Citizenship Behavior & 3.64 & 1.212 & $0.374^{* *}$ & $0.969^{* * *}$ & \\
\hline
\end{tabular}

Table 5 presents correlation coefficients between the research variables, and the results indicate the presence of significant correlation between variables (JE, QWL and OCB).

JE is average (Mean=3.24; SD.0.975) leading to a higher level of QWL (Mean=3.74; SD.1.22) which led to high level of OCB (Mean=3.64; SD. 1.212).

Table 5 reveals the existence of a positive correlation between JE and QWL $(\mathrm{R}=0.364 ; \mathrm{P}<0.01)$, which means that the high level of JE leads to higher QWL.

The table shows the existence of a positive correlation between JE and OCB $(\mathrm{R}=0.374 ; \mathrm{P}<0.01)$, which means that the high level of JE leads to higher OCB. According to Table 5, there is a positive correlation between QWL and $\mathrm{OCB}(\mathrm{R}=0.969 ; \mathrm{P}<0.01)$, which means that the high level of QWL leads to higher OCB.

\subsection{The Relationship between JE (Fit) and QWL}

Table 6. MRA results for JE (Fit) and QWL

\begin{tabular}{llll}
\hline The Variables of JE (Fit) & Beta & $\mathrm{R}$ & $\mathrm{R}^{2}$ \\
\hline 1) I have a relationship of friendship and love with all the members of the & 0.144 & 0.284 & 0.080 \\
$\quad$ working group. & & 0.250 & 0.062 \\
2) My job in the hospital enables me to exploit my skills and talents well. & 0.062 & 0.151 & 0.022 \\
3) My values and goals are consistent with the values of the organization. & $0.295^{* *}$ & $0.276^{* *}$ & 0.066 \\
4) I can achieve my professional goals through work in this organization. & 0.258 & 0.113 \\
5) I feel satisfied about my progress, during my professional career in this & 0.161 & 0.337 & 0.116 \\
$\quad$ organization. & 0.091 & 0.342 & \\
6) If I stay in this organization, I will achieve more of my goals. & 0.410 & & \\
\hline - Multiple Correlation Coefficients (MCC) $\quad 0.168$ & & \\
- $\quad$ The Value of Calculated F & 10.373 & & \\
- Degree of Freedom & 6,308 & & \\
- The Value of Indexed F & 2.80 & & \\
- Level of Significance & 0.01 & & \\
\hline $\mathrm{P}<.05 ; * * \mathrm{P}<.01$. & &
\end{tabular}


According to Table 6, the regression-coefficient between JE (Fit) and QWL is $\mathrm{R}=0.410$ and $\mathrm{R}^{2}=0.168$. This means that the QWL can be explained by the dimensions of JE (Fit), for example, "My values and goals are consistent with the values of the organization." $\left(\beta=0.295, R=0.151\right.$, and $\left.R^{2}=0.022\right)$, and "I can achieve my professional goals through work in this organization" $\left(\beta=0.276, \mathrm{R}=0.258\right.$, and $\left.\mathrm{R}^{2}=0.066\right)$.

Because of the calculated F (10.373) more than indexed F (2.80) at the statistical significance level of 0.01 , the null hypothesis is rejected.

6.4 The Relationship between JE (Links) and QWL

Table 7. The relationship between JE (Links) and QWL

\begin{tabular}{llll}
\hline The Variables of JE (Links) & Beta & $\mathrm{R}$ & $\mathrm{R} 2$ \\
\hline 1) I interact constantly with my colleagues at work. & 0.021 & 0.107 & 0.011 \\
2) A lot of co-workers depend on me to help achieve their work. & 0.112 & 0.285 & 0.081 \\
3) The current system allows the possibility of forming interacting work teams & 0.066 & 0.146 & 0.021 \\
4) Regular informal meetings are held to strengthen relationships among workers. & 0.053 & 0.258 & 0.066 \\
5) I feel that my current job satisfies my need for appreciation. & 0.031 & 0.337 & 0.113 \\
6) $\quad$ The organization allows all members to participate in work committees. & $0.226^{* *}$ & 0.342 & 0.116 \\
\hline - $\quad$ Multiple Correlation Coefficients (MCC) & 0.391 & & \\
- $\quad$ Determination of Coefficient (DF) & 0.145 & & \\
- The Value of Calculated F & 8,709 & & \\
- $\quad$ Degree of Freedom & 6,308 & & \\
- The Value of Indexed F & 2.80 & & \\
- Level of Significance & 0.01 & &
\end{tabular}

According to Table 7, the regression-coefficient between JE (Links) and QWL is $\mathrm{R}=0.391$ and $\mathrm{R}^{2}=0.145$. This means that the QWL can be explained by the dimensions of JE (Links), for example, "The organization allows all members to participate in work committees" $\left(\beta=0.226, R=0.342\right.$, and $\left.\mathrm{R}^{2}=0.116\right)$, and "I feel that my current job satisfies my need for appreciation" $\left(\beta=0.031, R=0.337\right.$, and $\left.\mathrm{R}^{2}=0.113\right)$.

Thus, the null hypothesis is rejected because JE (Links) and OC have a statistical relationship at the significance level of 0.01 .

\subsection{The Relationship between JE (Sacrifice) and QWL}

Table 8. The relationship between JE (Sacrifice) and QWL

\begin{tabular}{llll}
\hline The Variables of JE (Sacrifice) & Beta & $\mathrm{R}$ & $\mathrm{R}^{2}$ \\
\hline 1) I have a lot of freedom to choose how to set out my goals. & $0.166^{* *}$ & 0.097 & 0.009 \\
2) I feel that colleagues at work show me a lot of respect and appreciation. & 0.118 & 0.282 & 0.079 \\
3) Promotion opportunities in this job are excellent. & 0.076 & 0.160 & 0.025 \\
4) I get a good profit meeting level of my performance sufficiently. & 0.104 & 0.256 & 0.065 \\
5) The organization provides a distinct package of health care for workers. & $0.447^{* *}$ & 0.325 & 0.105 \\
6) The organization provides a distinct package of rewards at retirement. & 0.158 & 0.271 & 0.073 \\
\hline - $\quad$ Multiple Correlation Coefficients (MCC) & 0.370 & & \\
- $\quad$ Determination of Coefficient (DF) & 0.137 & \\
- The Value of Calculated F & 8,154 & \\
- Degree of Freedom & 6,308 & & \\
- $\quad$ The Value of Indexed F & 2.80 & & \\
- Level of Significance & 0.01 & & \\
Note. & $\mathrm{P}<.05 ; * \mathrm{P}<.01$. &
\end{tabular}

According to Table 8, the regression-coefficient between JE (Sacrifice) and QWL is $R=0.370$ and $\mathrm{R}^{2}=0.137$. This means that the QWL can be explained by the dimensions of JE (Sacrifice), for example, "I have a lot of freedom to choose how to set out my goals" ( $\beta=0.166, \mathrm{R}=0.097$, and $\left.\mathrm{R}^{2}=0.009\right)$, and "The organization provides a distinct 
package of health care for workers" ( $\beta=0.447, \mathrm{R}=0.325$, and $\left.\mathrm{R}^{2}=0.105\right)$. Therefore, there is enough empirical evidence to reject the null hypothesis.

\subsection{The Relationship between JE (Fit) and $O C B$}

Table 9. MRA results for JE (Fit) and OCB

\begin{tabular}{llll}
\hline The Variables of JE (Fit) & Beta & $\mathrm{R}$ & $\mathrm{R} 2$ \\
\hline 1) I have a relationship of friendship and love with all the members of the working group. & 0.203 & 0.310 & 0.096 \\
2) My job enables me to exploit my skills and talents well. & 0.043 & 0.272 & 0.073 \\
3) My values and goals are consistent with the values of the organization. & $0.307^{* *}$ & 0.152 & 0.023 \\
4) I can achieve my professional goals through work in this organization. & $0.261^{* *}$ & 0.257 & 0.066 \\
5) I feel satisfied about my progress, during my professional career in this organization. & 0.168 & 0.339 & 0.114 \\
6) If I stay in this organization, I will achieve more of my goals. & 0.079 & 0.345 & 0.119 \\
\hline - $\quad$ Multiple Correlation Coefficients (MCC) & 0.424 & \\
- Determination of Coefficient (DF) & 0.179 & \\
- The Value of Calculated F & 11,221 & \\
- Degree of Freedom & 6,308 & \\
- The Value of Indexed F & 2.80 & \\
- Level of Significance & 0.01 & \\
Note. $* *$ P $<.01$. & &
\end{tabular}

According to Table 9, the regression-coefficient between JE (Fit) and OCB is $\mathrm{R}=0.424$ and $\mathrm{R}^{2}=0.179$. This means that the OCB can be explained by the dimensions of JE (Fit), for example, "My values and goals are consistent with the values of the organization" $\left(\beta=0.307, \mathrm{R}=0.152\right.$, and $\left.\mathrm{R}^{2}=0.023\right)$, and "I can achieve my professional goals through work in this organization" $\left(\beta=0.261, \mathrm{R}=0.257\right.$, and $\left.\mathrm{R}^{2}=0.066\right)$.

Because of the calculated F (11.221) more than indexed F (2.80) at the statistical significance level of 0.01 , the null hypothesis is rejected.

\subsection{The Relationship between JE (Links) and OCB}

Table 10. The relationship between JE (Links) and OCB

\begin{tabular}{llll}
\hline The Variables of JE (Links) & Beta & $\mathrm{R}$ & $\mathrm{R} 2$ \\
\hline 1) I interact constantly with my colleagues at work. & 0.005 & 0.091 & 0.009 \\
2) A lot of co-workers depend on me to help achieve their work. & 0.119 & 0.296 & 0.087 \\
3) The current system allows the possibility of forming interacting work teams & 0.080 & 0.162 & 0.026 \\
4) Regular informal meetings are held to strengthen relationships among workers. & 0.043 & 0.257 & 0.066 \\
5) I feel that my current job satisfies my need for appreciation. & 0.022 & 0.339 & 0.114 \\
6) The organization allows all members to participate in work committees. & $0.342^{*}$ & 0.345 & 0.119 \\
\hline - $\quad$ Multiple Correlation Coefficients (MCC) & 0.389 & 0.151 & 9,161 \\
- Determination of Coefficient (DF) & 6,308 & \\
- The Value of Calculated F & 2.80 & \\
- Degree of Freedom & 0.01 & \\
- The Value of Indexed F & & \\
\hline
\end{tabular}

Note. $* \mathrm{P}<.05 ; * * \mathrm{P}<.01$.

According to Table 10, the regression-coefficient between JE (Links) and OCB is $\mathrm{R}=0.389$ and $\mathrm{R}^{2}=0.151$. This means that the OCB can be explained by the dimensions of JE, for example, "The organization allows all members to participate in work committees" $\left(\beta=0.342, \mathrm{R}=0.345\right.$, and $\left.\mathrm{R}^{2}=0.119\right)$, and "I feel that my current job satisfies 
my need for appreciation" $\left(\beta=0.022, \mathrm{R}=0.339\right.$, and $\left.\mathrm{R}^{2}=0.114\right)$. Thus, the null hypothesis is rejected because JE (Links) and OCB have a statistical relationship at the significance level of 0.01 .

\subsection{The Relationship between JE (Sacrifice) and OCB}

Table 11. The relationship between JE (Sacrifice) and OCB

\begin{tabular}{|c|c|c|c|c|}
\hline \multicolumn{2}{|c|}{ The Variables of JE (Sacrifice) } & \multirow{2}{*}{$\begin{array}{l}\text { Beta } \\
0160^{* * *}\end{array}$} & \multirow{2}{*}{$\begin{array}{l}\mathrm{R} \\
0.097\end{array}$} & \multirow{2}{*}{$\begin{array}{l}\mathrm{R} 2 \\
0.006\end{array}$} \\
\hline 1) & I have a lot of freedom to choose how to set out my goals. & & & \\
\hline 2) & I feel that colleagues at work show me a lot of respect and appreciation. & 0.097 & 0.291 & 0.084 \\
\hline 3) & Promotion opportunities in this job are excellent. & 0.086 & 0.176 & 0.030 \\
\hline 4) & I get a good profit meeting level of my performance sufficiently. & 0.135 & 0.262 & 0.068 \\
\hline 5) & The organization provides a distinct package of health care for workers. & $0.506^{* *}$ & 0.347 & 0.120 \\
\hline 6) & The organization provides a distinct package of rewards at retirement. & 0.159 & 0.287 & 0.082 \\
\hline - & Multiple Correlation Coefficients (MCC) & 0.388 & & \\
\hline - & Determination of Coefficient (DF) & 0.150 & & \\
\hline - & The Value of Calculated F & 9,080 & & \\
\hline - & Degree of Freedom & 6,308 & & \\
\hline - & The Value of Indexed F & 2.80 & & \\
\hline - & Level of Significance & 0.01 & & \\
\hline
\end{tabular}

Note. $* \mathrm{P}<.05 ; * * \mathrm{P}<.01$.

According to Table (11), the regression-coefficient between JE (Sacrifice) and OCB is $\mathrm{R}=0.388$ and $\mathrm{R}^{2}=0.150$. This means that the OCB can be explained by the dimensions of JE (Sacrifice), for example, "I have a lot of freedom to choose how to set out my goals" $\left(\beta=0.160, \mathrm{R}=0.079\right.$, and $\left.\mathrm{R}^{2}=0.006\right)$, and "The organization provides a distinct package of health care for workers" $\left(\beta=0.506, R=0.347\right.$, and $\left.\mathrm{R}^{2}=0.120\right)$. Therefore, there is enough empirical evidence to reject the null hypothesis.

\section{Research Finding}

Our findings support the view that the dimensions of JE (fit, links, and sacrifice) were positively related with QWL. The findings reveal that there is a positive relationship between JE and OCB.

The results support the view that the dimensions of JE were positively related with QWL and OCB. The results support the view that JE significantly influences QWL. The findings reveal that the JE was positively related with OCB.

Overall findings suggested that JE does affect QWL and OCB. Management should ensure that JE be applied in the organization through the encouragement of cooperative teamwork. Our findings support the view that more JE are more effective in achieving QWL and OCB. High JE will be more likely to achieve high QWL and OCB.

The results refer to a direct exponential impact relationship between JE, QWL and OCB. Employees with high JE enjoy higher production capacity compared to their counterparts with low-level JE as the availability of a high level of JE among employees leads to improving the quality of the relationship between employees and their bosses which leads to the improvement of the level of performance.

\section{Research Implications}

\subsection{Academic Implications}

Despite the theoretical appeal and importance of JE, we found no study that investigates the relationship between JE, QWL and OCB in Egypt. The paper provides some extensions to the nascent theory of JE by exploring its link with QWL and OCBEA and EP at Menoufia University Hospitals.

\subsection{Practical Implications}

There are some practical implications for managers in different organizations. They are as follows: 
1) It is important to have a work environment where employees would observe and experience a number of fair rules and procedures. Managements of the University should establish and maintain such a work environment. Otherwise, as discussed by Namazie and Frame (2007), frontline employees with better qualifications would leave the organization to work for in multinational firms.

2) JE is an employee retention strategy (Karatepe, 2011). University managers need to provide their employees with continuous training programs to enhance their skills so that such employees could deal with customers' requests effectively. Otherwise, employees who lack skills in listening and problem-solving would be unable to fulfill their role requirements. In addition, managements of the University should make sure that there are career opportunities for their employees. The lack of career opportunities in the organization would result in voluntary turnover.

3) It is important for University managers to make sure that their decision-making process is transparent. Employees who work in an environment, where they do not feel comfortable with managerial decision-making process regarding the selection and promotion of employees, need evidence that such decisions are made using fair formal procedures.

4) It is important to pay attention to JE as an effective strategy to improve relations between employees and their superiors on the one hand, and improve the level of JP within the organization, on the other hand. Also, promoting and supporting organizational culture encourages JE of employees. This can be achieved through the support and consolidation of mutual trust between the management of the organization, its leadership and its staff, as the high level of JE softens the negative effects of the work environment. This is achieved by increasing the capacity of the individual for compatibility with the organization and the development of relationships with others at all levels of the organization.

\section{Limitations of the Study}

The findings of this study need to be interpreted with the following limitations in mind. They are as follows:

1) This study used a time lag of two weeks for reducing problems emerging from common method bias. As a time-lagged study, it provides some evidence for temporal causality. However, using a longer period of time for testing the abovementioned relationships would be beneficial for establishing causality. In addition, it would be more useful for collecting data from multiple sources.

2) The present study used two variables. Testing such variables as QWL and OCB would be beneficial for our understanding concerning their associations with the dimensions of JE.

3) Employing cross-national research in future studies would enhance our understanding regarding the previously mentioned relationships. Finally, replication studies in other sectors would be useful for the generalizability of the findings.

\section{Conclusion}

According to importance of enhancement of QWL in organizations such as hospitals, one of the most important factors that plays positive role is JE of human resource of that organization. Then, in this research, we try to test this assumption until help managers to invest on JE of their organization and improve QWL and subsequence job performance of their personnel.

Mirkamali and Narenji Thani (2011) identify the factors related to faculty QWL. It has positive and significant relation with JE. Therefore, we can improve QWL by changing and manipulating JE dimensions.

Organizations want and need employees who will do those things that aren't in any job description. Evidence indicates that those organizations that have such employees outperform those that don't. As a result, some human subject studies are concerned with organizational citizenship behavior as a dependent variable.

OCB have often been conceptualized as inherently a socially desirable class of behaviors. It has been the purpose of this paper to strip away any biases and attributions for social desirability and to examine the behaviors in their strictly observable form. In doing so, a variety of motives can be examined as potential reasons why employees might exhibit OCB. Achievement, affiliation, and power are not new ideas, but the application of these motives to the study of OCB does provide a new lens through which to view OCB. Much research is still needed to validate the ideas expressed in this paper.

As defined by Organ (1988), OCB reflects a "good soldier syndrome" which is so necessary for the prosperity and good functioning of every organization. It means doing a better job, making an effort above and beyond formal requirements, and filling the gap between procedures and regulations on the one hand, and dynamic reality on the other. 
OCB is usually perceived as exerting exceptionally good behaviors for the sake of the organization and informally supporting its members. To date, and as far as we could find, no study has investigated the meaning and implications of OCB behaviors in the third sector.

Obviously, such behaviors are important to private organizations since they affect their competitiveness and profitability. Organizations should committed to increasing OCB among their paid employees.

Thus, OCB represents a powerful element of free-will conduct, most relevant in third-sector organizations, which highlight values of voluntary personal actions, especially among paid employees. Consequently, it is interesting to examine how OCB is manifested in interpersonal relationships within work units of the non-profit sector.

OCB is discretionary behavior that is not part of an employee's formal job requirements, but that nevertheless promotes the effective functioning of the organization (Robbins, 1996). Successful organizations need employees who will do more than their usual job duties and provide performance that is beyond expectations. In short, in order to reach that goal, full employees' JS, understanding their motivation and creating suitable work environments are most important things in management reality.

\section{References}

Bateman, T., \& Organ, D. (1983). Job Satisfaction and the Good Soldier: The Relationship Between Affect and Employee "Citizenship". Academy of Management Journal, 26, 587-595. http://dx.doi.org/10.2307/255908

Beauregard, T. A. (2007). Family Influences on the career life cycle. Career Choice in Management and Entrepreneurship: A Research Companion, 101-126.

Berry, L. L., \& Parasuraman, A. (1991). Marketing Service, Competing through Quality. New York: The Free Press.

Borman, C., Penner, L., Allen, T., \& Motowidlo, S. T. (2001). Personality Predictors of Citizenship Performance. International Journal of Selection and Assessment, 9(1/2), 52-66. http://dx.doi.org/10.1111/1468-2389.00163

Cammann, C., Fichman, M., Jenkins, D., \& Klesh, P. (1983). Assessing the Attitudes and Perceptions of Organizational Members. In Seashore, S., Lawler, E, Mirvis, P., \& Cammann, C. (Eds.), Assessing Organizational Change: A Guide to Methods, Measured and Practices. New York: Wiley.

Cohen, A., \& Vigoda, E. (2000). Do good citizens make good organizational citizens? An empirical examination of the relationship between general citizenship and organizational citizenship behavior in Israel. Administration and Society, 32, 596-625. http://dx.doi.org/10.1177/00953990022019597

Crossley, C. D., Bennett, R. J., Jex, S. M., \& Burnfield, J. L. (2007). Development of a Global Measure of Job Embeddedness and Integration into a Traditional Model of Voluntary Turnover. Journal of Applied Psychology, 92(4), 1031-1042. http://dx.doi.org/10.1037/0021-9010.92.4.1031

Efraty, D., Sirgy M. J., \& Claiborne, C. B. (1991). The effects of personal alienation on organizational identification: a quality-of-work life model. $J$ Bus Psychol, 6(Fall), 57-78. http://dx.doi.org/10.1007/BF01013685

Ehrhart, M., \& Naumann, S. (2004). Leadership and Procedural Justice Climate Citizenship Behavior as Antecedents of Unit-Level Organizational. Personnel Psychology, 57, 61-94. http://dx.doi.org/10.1111/j.1744-6570.2004.tb02484.x

Emmerik, H., \& Sanders, K. (2004). Social embeddedness and job performance of tenured and non-tenured professionals. Human Resource Management Journal, 14(1), 40-54. http://dx.doi.org/10.1111/j.1748-8583.2004.tb00111.x

Erturk, A., Yılmaz, C., \& Ceylan, A. (2004). Promoting Organizational Citizenship Behaviors: Relative Effects of Job Satisfaction, Organizational Commitment, and Perceived Managerial Fairness. METU Studies in Development, 31, 89-210.

Grandey, A. A., \& Cropanzano, R. (1999). The Conservation of Resources Model Applied to Work-Family Conflict and Strain. Journal of Vocational Behavior, 54(2), 350-370. http://dx.doi.org/10.1006/jvbe.1998.1666

Halbesleben, J. R. B., \& Wheeler, A. R. (2008). The Relative Roles of Engagement and Embeddedness in Predicting Job Performance and Intention to Leave. Work and Stress, 22(3), 242-256. http://dx.doi.org/10.1080/02678370802383962 
Havlovic, S. J. (1991). Quality of work life and human resource outcomes. Industrial Relations, 30(3), 469-479. http://dx.doi.org/10.1111/j.1468-232X.1991.tb00799.x

Heskett, J. L., Sasser, W. E. Jr., \& Schlesinger, L. A. (1997). The Service Profit Chain. New York: The Free Press.

Hian, C. C., \& Einstein, W. O. (1990). Quality of work life (QWL): What can unions do? S. A. M. Advanced Management Journal, 55(2), 17-22.

Holtom, B. C., \& Inderrieden, E. J. (2006). Integrating the unfolding model and job embeddedness model to better understand voluntary turnover. Journal of Managerial Issues, 18, 435-452. http://dx.doi.org/10.1016/j.orgdyn.2006.08.007

Holtom, B. C., Mitchell, T. R., \& Lee, T. W. (2006). Increasing Human and Social Capital by Applying Job Embeddedness Theory. Organizational Dynamics, 35(4), 316-331.

Karatepe, O. M., \& Ngeche, R. N. (2011). Does Job Embeddedness Mediate the Effect of Work Engagement on Job Outcomes? A Study of Hotel Employees in Cameroon. Journal of Hospitality Marketing and Management.

Konovsky, M., \& Organ, D. (1996). Dispositional and Contextual Determinants of Organizational Citizenship $\begin{array}{lllll}\text { Behavior. Journal of } & \text { Organizational }\end{array}$ http://dx.doi.org/10.1002/(SICI)1099-1379(199605)17:3<253::AID-JOB747>3.0.CO;2-Q

Konovsky, M., \& Pugh, S. (1994). Citizenship Behavior and Social Exchange. Academy of Management Journal, 37(3), 656-669. http://dx.doi.org/10.2307/256704

Lee, T. W., Mitchell, T. R., Sablynski, C. J., Burton, J. P., \& Holtom, B. C. (2004). The effects of organizational embeddedness on organizational citizenship, job performance, volitional absences, and voluntary turnover. Academy of Management Journal, 47, 711-722. http://dx.doi.org/10.2307/20159613

Lee, T. W., Mitchell, T. R., Wise, L., \& Fireman, S. (1996). An Unfolding Model of Voluntary Employee Turnover. Academy of Management Journal, 39(1), 5-36. http://dx.doi.org/10.2307/256629

Levine, M. F., Taylor, J., \& Davis, L. (1984). Defining quality of work life. Human Relations, 37(1), 81-104. http://dx.doi.org/10.1177/001872678403700105

MacKenzie, S., Podsakoff, M., \& Fetter, R. (1993). The Impact of Organizational Citizenship Behavior on Evaluations of Salesperson Performance. Journal of Marketing, 57, 70-80. http://dx.doi.org/10.2307/1252058

Mallol, C. M., Holtom, B. C., \& Lee, T. W. (2007). Job embeddedness in a culturally diverse environment. Journal of Business Psychology, 22(1), 35-44. http://dx.doi.org/10.1007/s10869-007-9045-x

Marta, J., Singhapakdi, A., Lee, D. J., Sirgy. M. J., Koonmee, K., \& Virakul, B. (2011). Perceptions about ethics institutionalization and quality of work life: Thai versus American marketing managers. Journal of Business Research. http://dx.doi.org/10.1016/j.jbusres.2011.08.019

Mathur, R. N. (1989). Quality of working life of women construction workers. New Delhi, India: Commonwealth Publishers.

Mitchell T. R., Holtom, B. C., Lee, T. W., Sablynski, C. J., \& Erez, M. (2001). Why People Stay: Using Job Embeddedness to Predict Voluntary Turnover. Academy of Management Journal, 44(6), 1102-1121. http://dx.doi.org/10.2307/3069391

Nemeth, C., \& Staw, B. (1989). The Tradeoffs of Social Control and Innovation in Small Groups and Organizations.

Ng, T. W. H., \& Feldman, D. C. (2010). The impact of job embeddedness on innovation-related behaviors. Human Resource Management, 49(6), 1067-1087. http://dx.doi.org/10.1002/hrm.20390

Organ, D. W. (1988). Organizational Citizenship Behavior: The Good Soldier Syndrome. Lexington, MA: Lexington Books.

Organ, D., \& Ryan, K. (1995). A Meta-Analytic Review of Attitudinal and Dispositional Predictors of Organizational Citizenship Behavior. Personnel Psychology, 48(4), 775-802. http://dx.doi.org/10.1111/j.1744-6570.1995.tb01781.x

Paine, J., \& Organ, D. (2000). The Cultural Matrix of Organizational Citizenship Behavior: Some Preliminary Conceptual and Empirical Observations. Human Resource Management Review, 10(1), 45-59. http://dx.doi.org/10.1016/S1053-4822(99)00038-8 
Park, K., \& Lee, K. E. (2004). A Study on the Relationship between Job Embeddedness and Turnover Intention in Korea. Korean Management Review, 33(5).

Podsakoff, M., \& MacKenzie, S. (1997). Impact of Organizational Citizenship Behavior on Organizational Performance: A Review and Suggestions for Future Research. Human Performance, 10(2), 133-151. http://dx.doi.org/10.1207/s15327043hup1002_5

Podsakoff, M., MacKenzie, S., Moorman, R., \& Richard, F. (1990). Transformational Leader Behaviors and Their Effects on Followers' Trust in Leader, Satisfaction, and Organizational Citizenship Behaviors. Leadership Quarterly, 1(2), 107-142. http://dx.doi.org/10.1016/1048-9843(90)90009-7

Podsakoff, M., MacKenzie, S., Paine, J., \& Bachrach, D. (2000). Organizational Citizenship Behaviors: A Critical Review of the Theoretical and Empirical Literature and Suggestions for Future Research. Journal of Management, 26(3), 513-563. http://dx.doi.org/10.1177/014920630002600307

Podsakoff, P. M., MacKenzie, S. B., \& Hui, C. (1993). Organizational Citizenship Behaviours and Managerial Evaluations of Employee Performance: A Review and Suggestions for Future Research. Research in Personnel and Human Resources Management, 11, 1-40.

Podsakoff, P. M., MacKenzie, S. B., Lee, J. Y., \& Podsakoff, N. P. (2003). Common Method Biases in Behavioral Research: A Critical Review of the Literature and Recommended Remedies. Journal of Applied Psychology, 88(5), 879-903. http://dx.doi.org/10.1037/0021-9010.88.5.879

Ravichandran, S., Gilmore, S. A., \& Strohbehn, C. (2007). Organizational Citizenship Behavior Research in Hospitality: Current Status and Future Research Directions. Journal of Human Resources in Hospitality and Tourism, 6(2), 59-77. http://dx.doi.org/10.1300/J171v06n02_04

Robbins, S. P. (1989). Organizational Behavior: Concepts, Controversies, and Applications. NJ: Prentice Hall

Robins, G., \& Wiersema, R. (1995). Organization \& Behavior. Princeton: New Jersey.

Scobel, D. N. (1975). Doing away with the factory blue. Harvard Business Review, 53, 132-142.

Seashore, S. E., Lawler, E. E., Mirvis, P., \& Cammann, C. (1983). Observing and Measuring Organizational Change: A Guide to Field Practice. New York: John Wiley.

Sekiguchi, T., Burton, J. P., \& Sablynski, C. J. (2008). The Role of Job Embeddedness on Employee Performance: The Interactive Effects with Leader-Member Exchange and Organization-Based Self-Esteem. Personnel Psychology, 61(4), 761-792. http://dx.doi.org/10.1111/j.1744-6570.2008.00130.x

Sirgy, M. J., Efraty, D., Siegel, P., \& Lee, D. J. (2001). A new measure of quality of work life (QWL) based on need satisfaction and spillover theory. Social Indicators Research, 55(3), 241-302. http://dx.doi.org/10.1023/A:1010986923468

Srinivas, E. S. (1994). Perceived quality of work life (PQWL) and organizational commitment: A study of managers in selected organizations. Management Research: Contemporary Issues. New Delhi: South Asia Publications.

Straw, R. J., \& Heckscher, C. C. (1984). QWL: New working relationships in the communication industry. Labor Studies Journal, 8(3), 261-274.

Turnipseed, D., \& Rassuli, A. (2005). Performance Perceptions of Organizational Citizenship Behaviors at Work: A bi-level Study among Managers and Employees. British Journal of Management, 16, 231-244. http://dx.doi.org/10.1111/j.1467-8551.2005.00456.x

Walton, R. E. (1974). QWL indicators: prospects and problems. Measuring the quality of working life: A symposium on Social Indicators of Working Life.

Williams, L., \& Anderson, S. (1991). Job Satisfaction and Organizational Commitment as Predictors of Organizational Citizenship and In-Role Behaviors. Journal of Management, 17(3), 601-617. http://dx.doi.org/10.1177/014920639101700305

Yao, X., Lee, T. W., Mitchell, T. R., Burton, J. P., \& Sablynski, C. J. (2004). Job Embeddedness: Current research and future directions. In R. Griffeth \& P. Hom (Eds.), Understanding employee retention and turnover ( $\mathrm{pp}$. 153-187). Greenwich, CT: Information Age. 


\section{Copyrights}

Copyright for this article is retained by the author(s), with first publication rights granted to the journal.

This is an open-access article distributed under the terms and conditions of the Creative Commons Attribution license (http://creativecommons.org/licenses/by/3.0/). 